\title{
Succinyl-CoA: 3-Ketoacid CoA-Transferase Deficiency
}

\author{
A CAUSE FOR KETOACIDOSIS IN INFANCY
}

\author{
J. Tyson Tildon and Marvin Cornblath \\ From the Department of Pediatrics, University of Maryland School of \\ Medicine, Baltimore, Maryland 21201
}

\begin{abstract}
A B S T R A C T To explain the cause of a unique form of severe and intermittent ketoacidosis in an infant who expired after 6 months of life, tissue culture fibroblasts and post mortem tissue were examined for enzyme activities that catalyze glucose and ketoacid oxidation. No measurable succinyl-CoA: 3-ketoacid CoAtransferase (CoA-transferase) activity could be detected in homogenates of the post mortem brain, muscle and kidney tissue, or in the cultured skin fibroblasts. Since seven other enzyme activities involving both glycolysis and ketone body oxidation were present in these same tissues, it was reasonable to conclude that the observed absence of CoA-transferase activity was not an artifact of homogenate preparation. It was concluded that the absence of CoA-transferase activity resulted in a loss of intracellular homeostasis leading to ketoacidosis. In addition, the absence of this enzyme appears to be a reasonable explanation for the alteration in glucose metabolism that was previously reported in fibroblasts from this patient.
\end{abstract}

\section{INTRODUCTION}

Pathologic ketosis is unusual in the newborn infant. In addition to diabetes mellitus and type I glycogen storage disease, several other metabolic abnormalities have been associated with ketosis in the neonate. These include defects in organic acid metabolism, such as ketotic hyperglycinemia $(1,2)$ and methylmalonic acidemia $(3,4)$ as well as in gluconeogenesis such as fructose-1,6-diphosphatase deficiency (5). Intermittent and mild ketonuria has been observed with lactic acid acidosis (6), and salicylate intoxication (7).

A preliminary account of this report was presented at the Annual Meeting of the Society for Pediatric Research, 30 April 1971.

Received for publication 30 July 1971 and in revised form 7 October 1971.
The mechanisms which are responsible for the increase in plasma and urine ketone bodies (i.e., $\beta$-hydroxybutyrate and acetoacetate) in these diseases have remained obscure. Possible explanations include an increased production, an under utilization, and an alteration of a specific regulatory process in ketone metabolism.

The recent demonstration of the metabolic pathway for ketone body oxidation by peripheral tissue provides evidence for the role of these substrates in mammalian metabolism $(8,9)$. In studies by Melichar, Drahota, and Hahn (10) and Persson and Gentz (11) it has been demonstrated that newborn infants have a four to sixfold increase in the level of plasma ketones the first days after birth. In rats, a similar increase in plasma ketone bodies has been correlated with an increase in ketone utilization by brain (12-14). Studies in this laboratory (8), by Klee and Sokoloff (13) and by Page, Krebs, and Williamson (15) have demonstrated that the increased utilization of these substrates resulted from the adaptive enzyme changes of $\beta$-hydroxybutyrate dehydrogenase and succinyl-CoA 3-ketoacid CoA-transferase activity during this period.

A unique opportunity to study these processes in the human was provided by a newborn infant who presented to the University of Maryland Hospital with persistent ketonemia and intermittent episodes of severe ketoacidosis. A detailed report of the clinical findings and laboratory data (16) indicated that he did not have any of the previously described causes of pathological ketosis. The episodes of severe ketoacidosis were precipitated by either an acute infection or by the administration of protein. Intensive therapy for 72-96 $\mathrm{hr}$ with parenteral glucose and alkali were necessary before he recovered from his ketoacidotic episodes. However, when glucose was the sole source of calories, the infant did well and had minimal ketonuria. 
The pattern of abnormal homeostasis in the presence of protein and the restoration to normal metabolism with glucose, as the only exogenous metabolite, appeared to be correlated with an abnormal metabolic process observed in the tissue culture fibroblasts derived from a skin biopsy from this infant (17). The results of that study demonstrated a striking reduction in glycolysis by the patient's fibroblasts. Additional experiments have indicated that the abnormal metabolism in these cells resulted from a possible metabolic inhibitor which accumulated in the presence of total media (i.e., protein and amino acids) but became normal after incubation for $12-18 \mathrm{hr}$ in the presence of glucose alone (18).

It is the purpose of this report to describe a deficiency in succinyl-CoA: 3-ketoacid CoA-transferase (CoAtransferase) in the post mortem tissues and the cultured fibroblasts of this infant, and to suggest a relationship which correlates this deficiency with the observed clinical manifestations and the biochemical studies of his tissue culture fibroblasts.

\section{METHODS}

Case summary, C. C. (UM 37-83-57). Boy C was born on 8 March 1968 to a $16 \mathrm{yr}$ old para 0000 Negro female whose past medical history was unremarkable. The 37 wk old pregnancy, labor, and delivery were uncomplicated. The father was $16 \mathrm{yr}$ old and healthy and the parents were unrelated. Physical examination at $2 \frac{1}{2} \mathrm{hr}$ of age revealed that the infant weighed $7 \mathrm{lb} .4 \mathrm{oz}(3289 \mathrm{~g})$ and was $20 \frac{1}{2}$ inches $(52 \mathrm{~cm})$ in length. The head circumference was $36 \mathrm{~cm}$; the chest circumference was $33 \mathrm{~cm}$. He was given routine care in the full-term nursery. On the 2 nd day of life he developed tachypnea that persisted throughout his nursery course, however, all known causes of tachypnea were excluded, but a urinalysis for ketones was not done.

The patient was fully digitalized $(50 \mu \mathrm{g} / \mathrm{kg})$ during the initial week of life and maintained on digitalis for 20 days without effect on the tachypnea or tachycardia. He gradually improved, took his formula well, was alert, and except for rapid and unlabored respiration appeared normal. On the 40th day of life he was discharged weighing $4.55 \mathrm{~kg}$ with a length of $53.5 \mathrm{~cm}$.

The patient was readmitted at 51 days of age after an acute illness associated with anorexia of $18 \mathrm{hr}$ duration. $\mathrm{He}$ had a severe metabolic acidosis $(\mathrm{pH}=6.93)$ with a strongly positive urine and serum acetone. Intensive parenteral fluids and alkali therapy, including sodium bicarbonate, tham, and glucose were necessary for 4 days before his $\mathrm{pH}$ was within normal limits.

The episode of severe ketotic acidosis was one of six that occurred throughout his life. During each episode, the glucose and hemograms were normal. Variable increases in plasma values for glycine, proline, lysine, and uric acid were observed. Plasma values for immunoreactive insulin were consistently decreased $(<10 \mu \mathrm{U} / \mathrm{ml})$; free fatty acids (FFA) consistently elevated (1.4 mEq/liter); and blood glucose normal $(60-90 \mathrm{mg} / 100 \mathrm{ml})$ when he was acidotic or euacidemic. The ketotic episodes followed acute infections, mild dehydration, and on two occasions after the administration of protein, once after intravenous plasma and the other after $1.5 \mathrm{~g} / \mathrm{kg}$ of soya bean protein. Each episode lasted 72-96 hr and required parenteral fluids. From the 20th wk to the 23rd wk of life, he was given only glucose water by mouth during which period his urinary ketones remained low.

At 24 wk of age, respiratory arrest occurred independent of the ketoacidosis. The patient required mechanical ventilation. 2 wk later a superimposed infection occurred which resulted in death at $6 \frac{1}{2}$ months of age. A post mortem examination was essentially unrevealing except for an extensive pneumonia and fatty infiltration of the liver. It was noted that the brain size was reduced. Tissue samples were obtained within $2 \mathrm{hr}$ after death and frozen at $-60^{\circ} \mathrm{C}$ for subsequent biochemical studies.

Enzyme assays. CoA-transferase catalyzes the stoichiometric and reversible transfer of CoA from succinyl-CoA to a 3-ketoacid. The assay procedure represents a modification (8) of the method described by Hersh and Jencks (19). Post mortem tissue and fibroblasts were homogenized in $0.3 \%$ deoxycholate in $0.25 \mathrm{~m}$ sucrose solution, or in water. The water homogenate was frozen and thawed three times. The assay procedure measured the reduction in absorption at $313 \mathrm{nM}$ of the enolate form of the acetoacetyl-CoA derivative in the presence of $\mathrm{MgCl}_{\mathbf{2}}$ at $\mathrm{pH}$ 8.4. The $1 \mathrm{ml}$ reaction mixture consisted of $3.0 \mathrm{mM} \mathrm{MgCl}_{2}, 67.0 \mathrm{~mm}$ tris

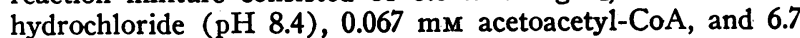
mM succinate. All assays were run in duplicate and were corrected for nonspecific changes. Optical density readings were recorded every $30 \mathrm{sec}$ for $4 \mathrm{~min}$ and the reaction was linear for this period. Enzyme activity was expressed as nanomoles acetoacetate formed/minute per milligram protein.

Acetoacetyl-CoA thiolase activity in the same homogenates was determined by the method of Williamson, Bates, and Krebs (20). $\beta$-Hydroxybutyrate dehydrogenase activity was determined by the method of Lehninger, Sudduth, and Wise (21).

The methods used for the assays of glycolytic enzymes which included triose phosphate dehydrogenase, enolase, phosphoglycerate kinase, pyruvate kinase, and phosphofructokinase were standard assay procedures as described in reference 22. Protein determinations were made either by the method of Lowry, Rosebrough, Farr, and Randall (23) or by ultraviolet absorption (24).

Tissue culture technique. Skin fibroblasts were grown from a punch biopsy specimen obtained 5 wk before the death of the patient. Control strains were derived from the foreskin of four normal males. The fibroblasts were maintained in Eagle's minimal media containing $10 \%$ fetal calf serum with added glutamine, penicillin, and streptomycin (17). Tests for contamination by bacteria and mycoplasma were negative.

Materials. Sodium and potassium acetoacetate were prepared by the hydrolysis of ethyl acetoacetate with alkali at $\mathrm{pH}$ 10.6. Succinyl-CoA was prepared by the method of Simon and Shemin (25). Succinic acid, succinic anhydride, Coenzyme A ( CoA), and acetoacetyl-CoA were purchased from the Sigma Chemical Co., St. Louis, Mo. All other chemicals were reagent grade.

\section{RESULTS}

Analysis of post mortem tissue. Quantitative values for CoA-transferase in the tissues of infants under 6 months of age have not been established. The results shown in Table $I$ indicated a reasonable agreement in the activity of CoA-transferase present in at least three tissues obtained within $5 \mathrm{hr}$ post mortem from 
three infants, ages 4 days, 23 days, and $4 \frac{1}{\text { months, }}$ whose causes of death were not associated with ketoacidosis. CoA-transferase activity was highest in the brain with decreasing values in the kidney and muscle tissues. In contrast, no CoA-transferase activity was present in any of the tissues from patient $C$ (Table I). Increasing the amount of homogenate protein in the reaction mixture to more than five times the concentration used for controls, still failed to reveal any CoAtransferase activity. Additional results also showed that the absence of CoA-transferase was not an artifact of tissue storage. Post mortem control tissue which was kept at room temperature for $36 \mathrm{hr}$ still contained measurable amounts of CoA-transferase activity and tissue stored for more than 7 months at $-60^{\circ} \mathrm{C}$ did not lose any appreciable enzyme activity. Several mixing experiments using the addition of active enzyme either from control homogenate (Table II) or purified CoA-transferase activity showed no evidence of either an inhibitor or an activator.

Using the same homogenate preparations, assays were made for thiolase activity in post mortem tissues from the patient and controls. In all of the patient's tissues examined, there were measurable amounts of thiolase activity (Table I). The values varied somewhat from those of the control tissues with the patient's brain homogenate having considerably less and his kidney homogenate somewhat higher activity than those of controls. Although there was considerable experimental difficulty in the measurement of $\beta$-hydroxybutyrate dehydrogenase in frozen post mortem tissue, the activity of this enzyme in the frozen post mortem liver sample from the patient was comparable with the activity of two control samples ( 0.79 vs. 0.50 and $1.12 \mathrm{nmoles} / \mathrm{min}$ per $\mathrm{mg}$ mitochondrial protein).

TABLE I CoA-Transferase and Thiolase Activities in Human Tissue

\begin{tabular}{|c|c|c|c|c|}
\hline & $\begin{array}{l}\text { Patient } \\
\text { C }\end{array}$ & $\begin{array}{c}\text { Control } \\
\text { A }\end{array}$ & $\begin{array}{c}\text { Control } \\
\text { B }\end{array}$ & $\begin{array}{l}\text { Control } \\
\text { C }\end{array}$ \\
\hline \multicolumn{5}{|c|}{$\begin{array}{l}\text { CoA-transferase, } \\
\text { nmoles/min per mg protein }\end{array}$} \\
\hline Brain & 0.0 & 15.9 & 10.2 & 15.7 \\
\hline Kidney & 0.0 & 4.2 & 0.7 & - \\
\hline Muscle & 0.0 & 1.4 & 0.7 & 0.8 \\
\hline \multicolumn{5}{|c|}{$\begin{array}{l}\text { Thiolase, } * \text { nmoles } / \min \\
\text { per mg protein }\end{array}$} \\
\hline Brain & 1.7 & 12.8 & 17.5 & 16.9 \\
\hline Kidney & 29.9 & 13.0 & 6.2 & - \\
\hline Muscle & 7.2 & 14.4 & 19.0 & 8.8 \\
\hline
\end{tabular}

* A comparison of enzyme activities for post mortem tissues from a patient with ketoacidosis which was not characterized by any of the known causes for this symptom. Controls were post mortem tissue from infants whose death was not associated with ketoacidosis. Ages at death for the controls were: (A) 4 days, (B) 23 days, (C) $4 \frac{1}{3}$ months. Enzymes were assayed as indicated in the text.
TABLE II

The Effect of Mixing Tissue Homogenates from Patient $C$ and Control on CoA-Transferase Activity

\begin{tabular}{|c|c|c|c|}
\hline \multirow[b]{2}{*}{ Cuvette } & \multicolumn{2}{|c|}{$\begin{array}{l}\text { Homogenate added to } \\
\text { reaction mixture* }\end{array}$} & \multirow[b]{2}{*}{$\begin{array}{l}\text { Enzyme } \\
\text { activity }\end{array}$} \\
\hline & $\begin{array}{l}\text { Patient } \\
\text { C }\end{array}$ & $\begin{array}{l}\text { Control } \\
\text { tissue }\end{array}$ & \\
\hline 1 & - & $20 \mu \mathrm{l}$ & $\begin{array}{c}\triangle O D / \min \\
0.043\end{array}$ \\
\hline 2 & $20 \mu \mathrm{l}$ & - & 0.000 \\
\hline 3 & $20 \mu l$ & $20 \mu l$ & 0.046 \\
\hline
\end{tabular}

* Three separate reaction cuvettes were incubated with the indicated amount of brain homogenate. The protein concentration for the patient's homogenate was $9.7 \mathrm{mg} / \mathrm{ml}$ and for the control it was $4.4 \mathrm{mg} / \mathrm{ml}$.

Studies using tissue-cultured fibroblasts. A $3 \%$ deoxycholate in $0.25 \mathrm{M}$ sucrose homogenate of cultured skin fibroblasts contained activities of CoA-transferase that were comparable with the lower values found in post mortem tissue (Table III). Using comparable protein concentrations in the reaction mixture, no measurable amounts of CoA-transferase could be demonstrated in the skin fibroblasts from the patient. In contrast, assays for both thiolase activity and triose phosphate dehydrogenate activity in these same homogenates gave similar results in cells from both the patient and the control (Table III).

Glycolytic enzymes. Assays for six glycolytic enzymes were made on the homogenates of post mortem tissue and for five enzymes in the homogenate of the tissue culture fibroblasts. In the fibroblasts from patient $C$, the activities for all of the enzymes measured were $40-130 \%$ those of control values (Fig. 1). The enzyme activities found in the post mortem tissue were consistently less than those of the controls (18-75\%). However, there was no correlation between the amount of a specific enzyme activity found in the tissue culture cells compared with that in the post mortem tissue. An

TABLE III

Enzyme Activities in Tissue Culture Fibroblasts

\begin{tabular}{llc}
\hline & Patient C & Contro \\
\hline $\begin{array}{l}\text { CoA-transferase, nmoles acetoacetate/ } \\
\text { min per mg protein }\end{array}$ & $0.0^{*}$ & 1.3 \\
$\begin{array}{l}\text { Thiolase, nmoles acetyl-CoA/min } \\
\text { per mg protein }\end{array}$ & 7.6 & 5.8 \\
$\begin{array}{l}\text { Triose phosphate dehydrogenase, } \\
U / m g \text { protein }\end{array}$ & 0.50 & 0.37 \\
\hline
\end{tabular}

* Limit of the assay is 0.2 nmoles/mg prótein. Control fibroblasts were explants from normal males of comparable ages (17).

CoA-Transferase Deficiency and Ketoacidosis 


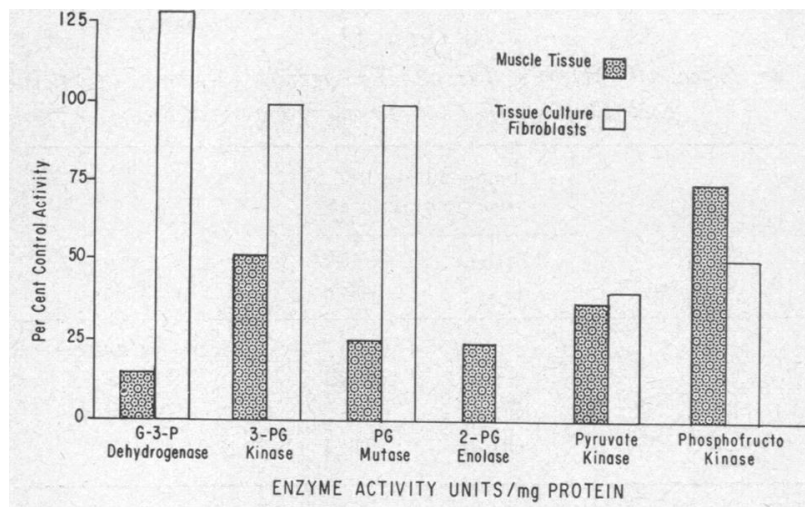

FIGURE 1 Specific activities for the glycolytic enzymes of post mortem tissue and tissue culture fibroblasts, except for 2-phosphoglycerate (2-PG) enolase which was not measured in the fibroblasts. The results for patient $C$ are expressed as per cent of the activity present in the control post mortem tissue and tissue culture fibroblasts.

exception to this was pyruvate kinase activity from the patient's tissue which was consistently $30-40 \%$ of the activity found in the control post mortem tissue and fibroblasts (Fig. 1).

Additional experiments compared the molecular properties of pyruvate kinase, glyceraldehyde-3-phosphate (G-3-P) dehydrogenase and phosphoglyceromutase from the patient's tissue to those from control tissue. The substrate specificity and the thermal labilities of the enzymes from the patient's tissue were similar to those obtained for the enzymes from control tissue. Mixing experiments also showed no inhibition of control enzyme by the homogenate of the patient's tissue. There was, however, greater inhibition of muscle pyruvate kinase by $3 \mathrm{~mm}$ phenylalanine in samples from the patient than in those from controls ( 1.45 vs. 8.26 enzyme $\mathrm{U} / \mathrm{mg}$ ). Except for this result and the general reduction in enzyme activity, all of the other comparative studies of enzyme activity showed no differences between patient and control tissue.

\section{DISCUSSION}

The demonstration of the enzymes necessary for ketone body oxidation in the brain, muscle, and kidney of neonatal human tissue strongly suggests that these substrates may be an important source of energy in human metabolism similar to that reported for the neonatal rat (12-14). Although the exact metabolic pathway for ketone utilization by the peripheral tissue of the newborn infant is yet to be defined, the evidence would suggest that for most tissues, ketone oxidation involves the conversion of $\beta$-hydroxybutyrate to acetoacetate. The acid is then activated to acetoacetyl-CoA followed by its clevage to two molecules of acetyl-CoA. This metabolic pathway and the enzyme for each step is outlined in Fig. 2. The role of CoA-transferase in human metabolism has not been rigorously documented previously, but it would appear reasonable to postulate that it plays a major role in acetoacetate activation and is a critical enzyme in ketone body oxidation.

The data presented demonstrate the absence of CoAtransferase in all of the post mortem tissues that were examined from patient $C$, and the absence of this enzyme could reasonably have caused the decreased ketone body utilization by peripheral tissues which would have resulted in the persistent ketonemia that was characteristic of this patient.

The results demonstrated the presence of the two other enzymes of ketone metabolism, i.e., $\beta$-hydroxybutyrate dehydrogenase and thiolase. The presence of $\beta$-hydroxybutyrate dehydrogenase in the liver of this patient, in amounts comparable with controls, would suggest that the observed ketosis in this patient was not related to a genetic error involving this enzyme. The thiolase activity in kidney and muscle tissue from the patient was comparable with the activity in control tissues; and, therefore, does not appear to be related to an altered metabolism in these tissues. On the

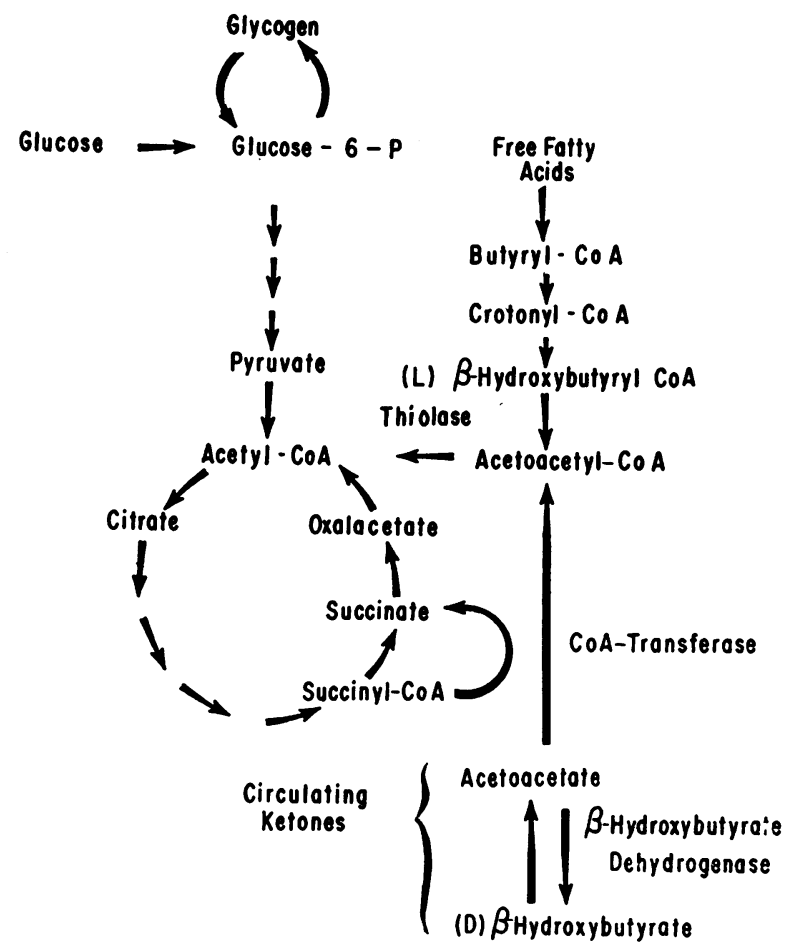

FIgURE 2 The interrelationship of the glycolytic, lipolytic, and ketonolic pathways in peripheral tissue. The enzymes $\beta$-hydroxybutyrate dehydrogenase, CoA-transferase, and thiolase are indicated to detail the metabolic fate of ketone bodies in peripheral tissue. 
other hand, the reduced activity in the brain might contribute to a disturbed homeostasis in this tissue.

A similar conclusion might also be appropriate for the reduced activities obtained for glycolytic enzymes. However, it has been reported that prolonged malnutrition causes a reduction in the specific activities of several glycolytic enzymes (26). It therefore seems reasonable to infer that these diminished enzyme activities were related to the reduced nutritional intake of this infant during the last month of his life rather than to his ketoacidosis. The terminal malnutrition of this infant might also explain the increased inhibitory effect of phenylalanine on the muscle pyruvate kinase of this infant since similar effects by both competitive and noncompetitive inhibitors on this enzyme have been observed by Metcoff (26). In contrast, it has been demonstrated that extended starvation does not affect CoA-transferase in rats $(8,9)$. Therefore, the absence of this enzyme activity was probably not the result of malnutrition.

The reversible transfer of $\mathrm{CoA}$ from succinate to acetoacetate by CoA-transferase, places this enzyme in a pivotal position in any interrelationship between carbohydrate metabolism and the oxidation of ketone bodies. Substrate oxidation studies of the patient's fibroblasts that contained no CoA-transferase activity, revealed a striking reduction of glucose utilization as compared with that by fibroblasts from normal controls $(17,18)$. This difference was the result of a diminished oxidation via the Embden-Myerhoff pathway. Measurements of enzyme activities demonstrate that this transient reduction in glucose utilization was probably not due to the absence of any of the glycolytic enzymes. Instead, the results suggest that the diminished glycolysis might have resulted from the presence of an endogenous inhibitor. It seems reasonable to infer that this inhibitor could have accumulated as the direct consequence of the absence of CoA transferase activity.

If the altered glycolysis in these fibroblasts is indicative of the metabolism by the other peripheral tissue of this patient, it can be inferred that this would cause an additional imbalance in an already disturbed homeostasis. Thus, an intermittent, severe ketoacidosis would be coincident with an increased protein catabolism after infection or starvation or with elevated serum amino acids after protein administration.

The factors which contribute to neonatal ketoacidosis are varied. Several metabolic errors such as methylmalonic aciduria and hyperglycinemia have been associated with increased ketosis, the mechanism of which remains obscure. It should be noted, however, that these metabolic errors seemed to be associated with enzyme deficiencies that result in an alteration of the intracellular concentration of succinyl-CoA. CoA-transferase deficiency as described above would also affect the intracellular concentration of succinyl-CoA. These results indicate that the possible interrelationship between altered succinyl-CoA concentrations and ketoacidosis requires further investigation.

The differential diagnosis of pathological ketosis in the neonate must include CoA-transferase deficiency. Because of the selective distribution of the enzyme and its absence in erythrocytes and leukocytes, the diagnosis in living patients would require a skin biopsy with serial propagation of fibroblasts in tissue culture in order to assay for the presence of CoA-transferase activity. Additional confirmation of the diagnosis would be the reversible diminished glycolysis in these fibroblasts (17).

\section{ACKNOWLEDGMENTS}

We wish to acknowledge the technical assistance of $\mathrm{Mr}$. David Sevdalian and Mr. Joseph Stevenson and we thank Doctors Raul Wapnir, Christa Dierks-Ventling, and Robert Gingell for measurements of the glycolytic enzymes.

This study was supported by research grants from the John A. Hartford Foundation and from the National Institutes of Child Health and Development (HD-03959-03).

\section{REFERENCES}

1. Childs, B., W. L. Nyhan, M. Borden, L. Bard, and R. E. Cooke. 1961. Idiopathic hyperglycinemia and hyperglycinuria: a new disorder of amino acid metabolism. Pediatrics. 27 : 522.

2. Hsia, Y. E., K. J. Scully, and L. E. Rosenberg. 1971. Inherited propionyl CoA carboxylase deficiency in ketotic hyperglycinemia. J. Clin. Invest. 50: 127.

3. Stokke, O., L. Elkjarn, K. R. Norum, J. Steen-Johnson, and S. Halvorsen. 1967. Methylmalonic acidemia. A new inborn error of metabolism which may cause fatal acidosis in the neonatal period. Scand. J. Clin. Lab. Invest. $20: 313$.

4. Oberholzer, V. G., B. Levin, E. A. Burgess, and W. F. Young. 1967. Methylmalonic aciduria. An inborn error of metabolism leading to chronic metabolic acidosis. Arch. Dis. Childhood. 42 : 492.

5. Baker, L., and A. I. Winegrad. 1970. Fasting hypoglycemia and metabolic acidosis associated with a deficiency of hepatic fructose-1,6-diphosphatase activity. Lancet. 2: 13 .

6. Haworth, J. C., J. D. Ford, and M. D. Younoszai. 1967. Familial chronic acidosis due to an error in lactate and pyruvate metabolism. Can. Med. Ass. J. 97: 773.

7. Winters, R. H. 1968. Salicylate Intoxication. In Pediatrics. H. L. Barnett, editor. Appleton-Century-Crofts, New York. 14th edition. 322.

8. Tildon, J. T., A. L. Cone, and M. Cornblath. 1971. CoA transferase in rat brain. Biochem. Biophys. Res. Commun. 43: 225.

9. Williamson, D. H., M. W. Bates, M. A. Page, and H. A. Krebs. 1971. Activities of enzymes involved in acetoacetate utilization in adult mammalian tissue. Biochem. J. 121 : 41. 
10. Melichar, V., Z. Drahota, and P. Hahn. 1965. Changes in the blood levels of acetoacetate and ketone bodies in newborn infants. Biol. Neonatorum. 8: 348.

11. Persson, B., and J. Gentz. 1966. The pattern of blood lipids, glycerol and ketone bodies during the neonatal period. Acta Paediat. Scand. 55: 333.

12. Itoh, T., and J. H. Quastel. 1970. Acetoacetate metabolism in infant and adult rat brain, in vitro. Biochem. $J$. 116: 641

13. Klee, C. B., and L. Sokoloff. 1967. Changes in $D(-) \beta$ hydroxybutyric dehydrogenase activity during brain maturation in the rat. J. Biol. Chem. 242: 3880 .

14. Hawkins, R. A., D. H. Williamson, and H. A. Krebs. 1971. Ketone body utilization by adults and suckling rat brain, in vivo. Biochem. J. $122: 13$.

15. Page, M. A., H. A. Krebs, and D. H. Williamson. 1971. Activities of enzymes of ketone body utilization in brain and other tissues of suckling rats. Biochem. J. 121: 49.

16. Cornblath, M., R. L. Gingell, G. A. Flemming, J. T Tildon, A. T. Leffler, and R. A. Wapnir. 1971. A new syndrome of keto-acidosis in infancy. J. Pediat. 79: 413.

17. Tildon, J. T., A. T. Leffler, M. Cornblath, and J. Stevenson. 1971. Abnormal glucose metabolism in skin fibroblasts cultured from a patient with a new syndrome of keto-aciduria. Pediat. Res. 5 : 518.

18. Tildon, J. T., M. Cornblath, and J. Stevenson. 1971.
Abnormal carbohydrate metabolism in genetic ketoacidosis. Fed. Proc. 30 : 78.

19. Hersh, L. B., and W. P. Jencks. 1967. Coenzyme A transferase kinetics and exchange reaction. J. Biol. Chem. 242: 3468.

20. Williamson, D. H., M. W. Bates, and H. A. Krebs. 1968. Activity and intracellular distribution of enzymes of ketone body metabolism in rat liver. Biochem. J. 108: 353.

21. Lehninger, A. L., H. D. Sudduth, and J. B. Wise. 1960. D- $\beta$-hydroxybutyrate dehydrogenase of mitochondria. J. Biol. Chem. 235: 2450.

22. Colowick, S. P., and N. O. Kaplan. 1955. Glyceraldehyde-3-phosphate dehydrogenase from muscle. Methods Enzymol. 1 : 401.

23. Lowry, O. H., N. J. Rosebrough, H. L. Farr, and R. J. Randall. 1951. Protein measurement with the folin phenol reagent J. Biol. Chem. 193: 265.

24. Warburg, O., and W. Christian. 1941. Wirkungsgruppe des Garungsferments Zymohexase. Biochem. Z. 310: 209.

25. Simon, E. J., and D. Shemin. 1953. The preparation of S-succinyl coenzyme A. J. Amer. Chem. Soc. 75: 2520.

26. Metcoff, J., S. Frenk, T. Yoshida, R. T. Pinedo, E. Kaiser, and J. D. L. Hansen. 1966. Cell composition and metabolism in Kwashiorkor. Severe protein-caloric malnutrition in children. Medicine (Baltimore). 45: 365. 